\title{
Correction To: On post-resonance backward whirl in an overhung rotor with snubbing contact
}

\author{
Mohammad A. AL-Shudeifat • Michael Friswell • Oleg Shiryayev • C. Nataraj
}

Published online: 28 August 2020

(C) Springer Nature B.V. 2020

\section{Correction To: Nonlinear Dyn https://doi.org/10.1007/s11071-020-05784-3}

On the title page, author Oleg Shiryavev should be spelled as Oleg Shiryayev.
The original article has been corrected.

Publisher's Note Springer Nature remains neutral with regard to jurisdictional claims in published maps and institutional affiliations.

The original article can be found online at https://doi.org/10. 1007/s11071-020-05784-3.

M. A. AL-Shudeifat $(\varangle)$

Department of Aerospace Engineering, Khalifa University of Science and Technology, PO Box 127788, Abu Dhabi, United Arab Emirates

e-mail: mohd.shudeifat@ku.ac.ae

M. Friswell

College of Engineering, Swansea University, Bay Campus,

Fabian Way, Crymlyn Burrows, Swansea SA1 8EN, UK

e-mail:m.i.friswell@swansea.ac.uk

\section{O. Shiryayev}

Department of Mechanical Engineering, University of Alaska Anchorage, 3211 Providence Dr., Anchorage, AK 99508, USA

e-mail: oshiryayev@alaska.edu

C. Nataraj

Villanova Center for Analytics of Dynamic Systems, Villanova University, 800 Lancaster Ave., Villanova, PA 19085, USA

e-mail: c.nataraj@villanova.edu 